\title{
Technological Gaps in Adoption of Improved Soybean Production Technology by Soybean Growers in Dahod District, Gujarat
}

\author{
R. G. Machhar, S. K. Patel ${ }^{*}$, H. L. Kacha, U. M. Patel, G. D. Patel, R. Radha Rani \\ Krishi Vigyan Kendra, Anand Agricultural University, Campus Dahod, Gujarat, India \\ Email address: \\ sppiari@gmail.com (S. K. Patel)
}

\section{To cite this article:}

R. G. Machhar, S. K. Patel, H. L. Kacha, U. M. Patel, G. D. Patel, R. Radha Rani. Technological Gaps in Adoption of Improved Soybean Production Technology by Soybean Growers in Dahod District, Gujarat. American Journal of Agriculture and Forestry. Vol. 3, No. 6, 2015, pp. 276-279. doi: 10.11648/j.ajaf.20150306.16

\begin{abstract}
The present study was conducted in Dahod district of Gujarat State, India. Fifteen villages of Dahod district and ten farmers from each village were selected randomly for the study. Thus, in all, 150 soybean growers constituted the sample for this investigation. The data for this study was collected by arranging personal interview and filling up of the survey performa. The results of the study revealed that the technological gap of all categories of respondents was found to be negatively and significantly related with the independent variables viz. level of knowledge, education, social participation, source of information utilized and cropping intensity. Further, it was found that technological gap among the marginal farmers' was negatively and significantly related with one independent variable i.e. farm implements. Age was positively and significantly related with the technological gap in recommended soybean production technology.
\end{abstract}

Keywords: Soybean, Adoption, Technological Gap, Dahod, Gujarat

\section{Introduction}

Soybean [Glycine max (L) Marril] belongs to family Leguminoseae, sub family Papilionaideae and genus Glycine. It is mainly grown in kharif season and occupies second place in the world, following groundnut in oilseed production. Soybean has now established as an economically important leguminous crop, known for its high valued protein, oil, food, feed and industrial application. It enriches the soil by fixing nitrogen in symbiosis with bacteria. In the international world trade markets, soybean is ranked number one among the major oil crops (Specht et al., 1999). In India, the consumption of oil has been increasing steadily as a result of rise in population and living standard of the people (Chung and Sing, 2008). Presently soybean is grown in many countries of the world like USA, China, India, Brazil and Argentina. In India, the total area under soybean cultivation is 106.95 lakh ha with the production and the productivity of 126.78 lakh tonnes and $1185 \mathrm{~kg} \mathrm{ha}^{-1}$, respectively (Anon., 2012). In India major States growing soybean are Madhya Pradesh, Maharashtra, Rajasthan, Andhra Pradesh, Karnataka, Chattisgarh and Gujarat. Major soybean growing districts of Gujarat state are Dahod, Sabarkantha, Bharuch, Vadodara, Panchmahals and Amreli. Farmers of Dahod district have changed their old cropping pattern to new cropping pattern i.e. diversified maize crop into soybean crop (Patel et al, 2014 and Kacha \& Patel, 2015).The area of soybean crop in the Dahod Districtis increasing very fast since year 2005 to 2011 i.e. 0 to 35000 ha but the productivity of soybean crop is very low as compare to its potentiality (Anon., 2013 and Machhar et al., 2015). So, there is a need to find out the gap existing between technologies available and actually applied by farmers in their fields (Singh et al., 2006 and Bhatiya et al., 2006). Therefore, a study entitled "A study of technological gaps in adoption of improved soybean production technology by soybean growers in Dahod district" was undertaken.

\section{Methodology}

Fifteen villages of Dahod district and ten farmers from each village were selected randomly for the study. Thus, in all, 150 soybean growers constituted the sample for this investigation. The method used for collecting data was the well structured personal interaction schedule prepared in 
English, keeping in view the objectives of the study by referring the review of related literature, popular articles and guidance provided by senior officials. Questions and statements on each and every aspect of the problem were framed in order to study with maximum possible accuracy, clarity and objectivity.

The data were collected through personal interaction with the soybean growers. Before administrating the schedule, the investigators have introduced themselves as soybean growers. The objectives of the study were explained to them with a view to facilitate them in giving correct responses. The majority of soybean growers were interviewed either at their residence or at farm. The questions from the interview schedule were asked one by one and their responses were recorded on the spot. Possible care was taken to maintain friendly atmosphere to get unbiased responses from the soybean growers. During data collection, investigators have also gathered the useful information through observation and informal discussion with the soybean growers for its implication at the time of interpretation of data.

The data of this study was collected by arranging personal interview and survey performa. To determine the extent of adoption of production technology of soybean cultivation, adoption quotient developed by Sharma and Intodia (1991) was used. The technological gap was computed by following formula developed by All India Coordinated Project in Extension Education (AICPEE) and Indian Agricultural Research Institute (IARI), New Delhi. The data was analyzed in light of objectives.

\section{Results and Discussions}

Table 1. Distribution of soybean growers according to age $(n=150)$.

\begin{tabular}{llll}
\hline Sr. No. & Age group & Number & Percent \\
\hline 1. & Young age(Up to 30 year) & 19 & 12.67 \\
2. & Middle age(31 to 50 year) & 110 & 73.33 \\
3. & Old age(Above 50 year) & 21 & 14.00 \\
& Total & 150 & 100.00 \\
\hline
\end{tabular}

The data depicted in Table 1 shows that maximum number of soybean growers (73.33 per cent) were found in middle age group followed by old age 14.00 per cent. Remaining 12.67 per cent soybean growers were found in young age.

Table 2. Distribution of soybean growers according to their level of education $(n=150)$.

\begin{tabular}{llll}
\hline Sr. No. & Level of education & Number & Percent \\
\hline 1. & Illiterate & 18 & 12.00 \\
2. & Primary education (Up to VII Std.) & 43 & 28.67 \\
3. & Secondary education (VIII to X Std.) & 68 & 45.33 \\
4. & Higher Secondary education (XI to XII Std.) & 18 & 12.00 \\
5. & College and above education & 03 & 2.00 \\
& Total & 150 & 100.00 \\
\hline
\end{tabular}

The data depicted in Table 2 indicate that 45.33 per cent soybean growers were educated up to secondary education followed by 28.67 per cent were educated up to primary level. Percent of soybean growers that were illiterate was 12.00 percent and equal to the group with higher secondary education. Remaining only 2.00 per cent were having college and above education.

A look into Table 3 reveals that 64.00 per cent Soybean growers had no membership in any organization. While a little less than one-forth of them (24.67 per cent) had membership in more than one organization. Only 8.00 per cent soybean growers had membership in one organization. Remaining 3.33 per cent soybean growers were found holding position in various organizations.

Table 3. Distribution of soybean growers according to their social participation $(n=150)$.

\begin{tabular}{llll}
\hline Sr. No. & Social participation & Number & Percent \\
\hline 1. & No membership & 96 & 64.00 \\
2. & Membership in one organization & 12 & 08.00 \\
3. & Membership in more than one organizations & 37 & 24.67 \\
4. & Holding position & 05 & 03.33 \\
& Total & 150 & 100.00 \\
\hline
\end{tabular}

Table 4. Distribution of soybean growers according to their size of land holding $(n=150)$.

\begin{tabular}{llll}
\hline Sr. No. & Size of land holding & Number & Percent \\
\hline 1. & Marginal farmers (Up to 1.00ha) & 56 & 37.33 \\
2. & Small farmers (1.01 to 2.00 ha) & 81 & 54.00 \\
3. & Medium farmers (2.01 to 4.00 ha) & 11 & 7.33 \\
4. & Large farmers (Above 4.00 ha) & 02 & 1.34 \\
& Total & 150 & 100.00 \\
\hline
\end{tabular}

The data presented in Table 4 shows that more than half of the soybean growers (54.00 per cent) were found to have small size of farm followed by 37.33 and 7.33 per cent with marginal (up to $1.00 \mathrm{ha}$ ) and medium (2.01 to $4.00 \mathrm{ha}$ ) size of farm, respectively. Only a mere, 1.34 per cent soybean growers were found to have large size of farm.

Table 5. Distribution of soybean growers according to their cropping intensity $(n=150)$.

\begin{tabular}{llll}
\hline Sr. No. & Cropping intensity & Number & Percent \\
\hline 1. & 100 & 04 & 2.70 \\
2. & 125 & 01 & 0.07 \\
3. & 128 & 01 & 0.07 \\
4. & 150 & 06 & 4.00 \\
5. & 167 & 01 & 0.07 \\
6. & 193 & 01 & 0.07 \\
7. & 200 & 133 & 88.70 \\
8. & 217 & 01 & 0.07 \\
9. & 228 & 01 & 0.07 \\
10. & 300 & 01 & 0.07 \\
& Total & 150 & 100.00 \\
\hline
\end{tabular}

A look into Table 5 shows that 88.70 per cent soybean growers obtained 200 per cent cropping intensity followed by 150 and 100 per cent cropping intensity got by 4.00 and 2.00 per cent soybean growers, respectively. Only 0.07 per cent soybean growers were having 125,128,167,193,217,228 and 300 per cent cropping intensity. 
Table 6. Distribution of soybean growers according to their occupation(n 150).

\begin{tabular}{llll}
\hline Sr. No. Occupation & \multicolumn{2}{l}{ Number } & Percent \\
\hline 1 & Only farming & 08 & 5.33 \\
2 & Farming + Animal Husbandry & 80 & 53.33 \\
3 & Farming + Animal Husbandry + Labour work & 61 & 40.67 \\
4 & Farming + Animal Husbandry + Service & 01 & 0.67 \\
& Total & 150 & 100.00 \\
\hline
\end{tabular}

The data presented in Table 6 revealed that more than half (53.33 per cent) of the soybean growers were engaged in farming along with Animal Husbandry followed by 40.67 per cent of the respondents who were engaged in farming + animal husbandry + labour work. Remaining 5.33 and 0.67 per cent of the soybean growers were engaged in only farming and Farming + Animal Husbandry + Service, respectively.

Table 7. Distribution of soybean growers according to their annual income $(n=150)$.

\begin{tabular}{llll}
\hline Sr.No. & Annual income & Number & Percent \\
\hline 1. & Less than 20,000 & 01 & 0.67 \\
2. & 20,000 to 30,000 & 07 & 4.67 \\
3. & 31,000 to 50,000 & 84 & 56.00 \\
4. & 50,000 to 70,000 & 41 & 27.33 \\
5. & 70,000 and above & 17 & 11.33 \\
& Total & 150 & 100.00 \\
\hline
\end{tabular}

The data presented in Table 7 shows that 56.00 per cent soybean growers were having annual income between 31,000 to 50,000 followed by 50,000 to 70,000 and 70,000 and above annual income with 27.33 and 11.33 per cent, respectively. Remaining 4.67 and 0.67 per cent soybean growers were found with 20,000 to 30,000 and less than 20,000 annual income, respectively.

Table 8. Distribution of soybean growers according to their level of extension participation $(n=150)$.

\begin{tabular}{llll}
\hline Sr. No. & Extension participation & Number & Percent \\
\hline 1. & Low $(<1.94$ score $)$ & 02 & 01.33 \\
2. & Medium (Between 1.94to16.79score) & 126 & 84.00 \\
3. & High $(16.79>$ score $)$ & 22 & 14.67 \\
& Total & 150 & 100.00 \\
\hline
\end{tabular}

Mean: 9.36, S.D. 7.42

The result of the study reported in Table 8 reveals that more than four-fifth ( 84.00 per cent) of the soybean growers had medium extension participation whereas less than onefifth (14.67 per cent) had high extension participation. Only a mere, 1.33 per cent soybean growers had low extension participation.

Table 9. Distribution of soybean growers according to their sources of information utilized $(n=150)$.

\begin{tabular}{llll}
\hline Sr. No. & Sources ofinformation & Number & Percent \\
\hline 1. & Low (<9.04 score) & 85 & 56.67 \\
2. & Medium (Between 9.04to 17.99score) & 42 & 28.00 \\
3. & High (>17.99 score) & 23 & 15.33 \\
& Total & 150 & 100.00 \\
\hline
\end{tabular}

Mean: 13.52, S.D. 4.48
A perusal of data presented in Table 9 reveals that more than half (56.67 per cent) of the soybean growers had low sources of information utilized. Whereas one - forth $(28.00$ per cent) and 15.33 per cent of the soybean growers had high and low sources of information utilized, respectively.

Table 10. Distribution of soybean growers according to their level of adoption $(n=150)$.

\begin{tabular}{llll}
\hline Sr. No. & Level of adoption & Number & Percent \\
\hline 1. & Low (<6.69 score) & 13 & 8.67 \\
2. & Medium (Between 6.69 to 9.76 score) & 119 & 79.33 \\
3. & High (>9.76 score) & 18 & 12.00 \\
& Total & 150 & 100.00 \\
\hline
\end{tabular}

Mean: 8.23 , S.D. 1.54

The data presented in Table 10 reveals that more than three-fifth (79.33 per cent) of the soybean growers had medium level of adoption whereas 12.00 and 8.67 per cent of the soybean growers had high and low level of adoption, respectively.

Table 11. Distribution of soybean growers according to their level of adoption and technological gap in package of practices $(n=150)$.

\begin{tabular}{lllll}
\hline Sr. No. & Package of practices & Number & $\begin{array}{l}\text { Adoption } \\
\text { Per cent }\end{array}$ & $\begin{array}{l}\text { Technological } \\
\text { gap }\end{array}$ \\
\hline 1. & Soil & 147 & 98.00 & 02.00 \\
2. & Improved Variety & 146 & 97.33 & 02.67 \\
3. & Seed rate & 140 & 93.33 & 06.67 \\
4. & Seed Treatment & 37 & 24.67 & 75.33 \\
5. & Time of sowing & 138 & 92.00 & 08.00 \\
6. & System of sowing & 133 & 88.67 & 11.33 \\
7. & Sowing distance & 36 & 24.00 & 76.00 \\
8. & Manuring & 91 & 60.67 & 39.33 \\
9. & Chemical Fertilizer & 110 & 73.33 & 26.67 \\
10. & Weeding & 108 & 72.00 & 28.00 \\
11. & Plant protection & 01 & 0.67 & 99.33 \\
12. & Time of harvesting & 147 & 98.00 & 02.00 \\
\hline
\end{tabular}

The data presented in Table 11 reveals that maximum technological gap was observed in plant protection ( 99.33 per cent) followed by sowing distance (76.00 percent), seed treatment (75.33 per cent), use of manure (39.33 per cent) weeding (28.00 per cent), use of chemical fertilizer (26.67 per cent) and system of sowing (11.33 per cent).Less than 10.00 percent technological gap was found in time of sowing (8.00 per cent), seed rate( 6.67 per cent), use of improved variety( 2.67 per cent), time of harvesting $(2.00$ per cent and selection of soil(2.00 per cent) in descending order.

Table 12. Constraints faced by soybean growers in adoption of improved cultivation practices $(n=150)$.

\begin{tabular}{lllll}
\hline Sr.No. & Constraints & Number & \multicolumn{2}{l}{ Percent } \\
\hline 1 & Shattering loss in existing varieties & 67 & 44.67 & I \\
2 & $\begin{array}{l}\text { Unavailability of sufficient labour in } \\
\text { time }\end{array}$ & 59 & 39.33 & II \\
3 & Lack of technical guidance & 35 & 23.33 & III \\
4 & $\begin{array}{l}\text { High cost of insecticide/ pesticide and } \\
\text { weedicide }\end{array}$ & 32 & 21.33 & IV \\
5 & $\begin{array}{l}\text { Fluctuating market price of soybean } \\
6\end{array}$ & 30 & 20.00 & V \\
\hline
\end{tabular}


The data presented in Table 12 reveals that constraints faced by soybean growers in adoption of improved cultivation practices of soybean were shattering loss in existing varieties (44.67 per cent) followed by unavailability of sufficient labour in time (39.33 percent) and Lack of technical guidance(23.33 percent).Remaining constraints were high cost of insecticide/ pesticide and weedicide, fluctuating market price of soybean and high cost of fertilizer with $21.33,20.00$ and 13.33 per cent, respectively.

\section{Conclusion}

As per results, majority soybean growers were in age of 31 to 50 years, secondary education, no membership in any social organization, small farmers, having farming with animal husbandry as the main occupation, medium extension participation, low use of sources of information and medium level of adoption.

The technological gap of soybean growers was found to be the highest in plant protection measures followed by sowing distance, seed treatment and manuring.

Constraints faced by soybean growers in adoption of improved cultivation practices of soybean were shattering loss in existing varieties followed by unavailability of sufficient labour in time and Lack of technical guidance.

\section{References}

[1] Anonymous (2012).Soybean Processors Associations of India (2012).

[2] Anonymous (2013). Comprehensive District Agricultural Plan (2013).
[3] Chung, G. and Singh. R.J. (2008). Broadening the genetic base of soybean. A multidisciplinary approach. Plant Sci., 27: 295-341.

[4] Patel, S.K., Machhar, R.G., Kacha, H.L., Trivedi, M.M. and Patel, U.M. (2014). Crop Diversification for Sustainable Development. Spring, 3 (4).

[5] Sharma, F. L. and Intodia, S. L., (1991). Technological gap in adoption of improved animal husbandry practices. Maharashtra J. Extn, Edn., 10 (2): 128-132.

[6] Kacha, H.L. and Patel, S.K. (2015). Impact of Frontline Demonstration on Okra (Abelmaschus esculentus (L.) Moench) Yield Improvements. Journal of AgriSearch, 2(1): 69-71.

[7] Machhar, R.G., Sadhu, A.C., Patel, S.K. and Patel, V.J. (2015). Residual effect of organic manures, biofertilizers \& fertilizers on soybean-wheat sequence under middle Gujarat. Green farming, Vol. 6 (5): 1042-1045.

[8] Specht, J.E., D.J. Hume, and S.V. Kumudini. 1999. Soybean yield potential - a genetic and physiological perspective. Crop Sci. 39:1560-1570.

[9] Piara Singh, Vijaya, D., Srinivas, K., and Wani, S.P. (2006). Potential Productivity, Yield Gap, and Water Balance of Soybean-Chickpea Sequential Systematic Selected Benchmark Sites in India. An Open Access Journal published by ICRISAT (SAT e Journal), 2(1): 1-50.

[10] Bhatia VS, Singh Piara, Wani SP, Kesava Rao AVR and Srinivas K. 2006. Yield Gap Analysis of Soybean, Groundnut, Pigeonpea and Chickpea in India Using Simulation Modeling. Global Theme on Agroecosystems Report no. 31. Patancheru 502 324, Andhra Pradesh, India: International Crops Research Institute for the Semi-Arid Tropics (ICRISAT). $156 \mathrm{pp}$. 